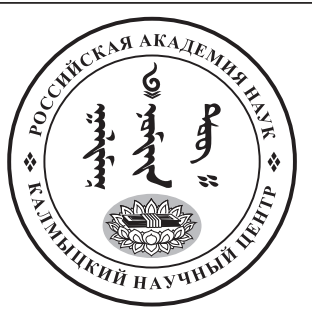

Published in the Russian Federation

Oriental Studies (Previous Name: Bulletin of the Kalmyk Institute

for Humanities of the Russian Academy of Sciences)

Has been issued as a journal since 2008

ISSN: 2619-0990; E-ISSN: 2619-1008

Vol. 13, Is. 4, pp. 1103-1120, 2020

DOI: $10.22162 / 2619-0990-2020-50-4-1103-1120$

Journal homepage: https://kigiran.elpub.ru

УДК 821.512 .37

DOI: $10.22162 / 2619-0990-2020-50-4-1103-1120$

\title{
Эмотивные глаголы в калмыцком героическом эпосе «Джангар»
}

\section{Нина Михайловна Мулаева}

${ }^{1}$ Калмыцкий научный центр РАН (д. 8, ул. И. К. Илишкина, Элиста 358000, Российская Федерация) кандидат филологических наук, научный сотрудник

iD 0000-0001-8395-849X. E-mail: mulaevanm@kigiran.com

(C) КалмНЦ РАН, 2020

(C) Мулаева Н. М., 2020

Аннотация. Введение. В современной лингвистике большое внимание уделяется изучению национально-культурной специфики фукционирования и семантики эмотивной лексики. В калмыцком языке эмотивная лексика не была объектом специального изучения. Цель работы: выявить и классифицировать лексико-семантические группы эмотивных глаголов в текстах эпоса «Джангар» и проанализировать функционирование глаголов, которые называют «базовые» эмоции: радость (жсирhx 'быть счастливым, блаженствовать', байрлх 'радоваться'), страх (әәх 'бояться, пугаться, страшиться, опасаться', ичх 'стыдиться') и глагол внешнего (физического) проявления эмоций (инәх 'смеяться'). Материалом исследования являются эмотивные глаголы, зафиксированные в 28 текстах разновременных записей калмыцкого героического эпоса «Джангар», объединенных в репертуарные циклы или представленных отдельными песнями. Результаты. В ходе исследования выяснено, что эмотивные глаголы эпоса можно разделить на шесть лексико-семантических групп (ЛСГ); в частотном отношении ЛСГ «глаголы отрицательных эмоциональных состояний» преобладает над ЛСГ «глаголы положительных эмоциональных состояний». В ЛСГ «Глаголы положительных эмоциональных состояний», представленном двумя глаголами, доминирует глагол ж⿻̧и $x$, который в иллюстративных примерах чаще всего отражает состояние наивысшего счастья, заключающееся в мире, спокойствии и благополучии страны Бумбы в целом; глагол байрлх употребляется для называния кратковременного эмоционального состояния радости конкретного персонажа. В ЛСГ «глаголы отрицательных эмоциональных состояний» по частотности преобладает глагол әәх; выявлено, что эмоция страха возникает по следующим причинам: страх невыполнения приказа богдо; страх нарушения клятвы; страх опозорить имя. Отмечены единичные случаи употребления глаголов, называющих эмоции печали (энлх), стеснения (эмәx), досады (hyндx). В текстах эпоса отсутствуют эмотивные глаголы, которые относятся к семантическим группам: глаголы увлечения, глаголы любви и ненависти, глаголы преклонения и самоуничижения.

Ключевые слова: эмотивные глаголы, эмоциональное состояние, лексико-семантические группы, калмыцкий язык, эпос «Джангар» 
Благодарность. Исследование проведено в рамках государственной субсидии - проект «Устное и письменное наследие монгольских народов России, Монголии и Китая: трансграничные традиции и взаимодействия» (номер госрегистрации: АААА-А19-119011490036-1).

Для цитирования: Мулаева Н. М. Эмотивные глаголы в калмыцком героическом эпосе «Джангар»// Oriental Studies. 2020. Т. 13. № 4. С. 1103-1120. DOI: 10.22162/2619-0990-202050-4-1103-1120

UDC 821.512.37

DOI: $10.22162 / 2619-0990-2020-50-4-1103-1120$

\title{
Kalmyk Heroic Epic of Jangar: Emotive Verbs
}

\author{
Nina M. Mulaeva ${ }^{1}$ \\ ${ }^{1}$ Kalmyk Scientific Center of the RAS (8, Ilishkin St., Elista 358000, Russian Federation) \\ Cand. Sc. (Philology), Research Associate \\ iD 0000-0001-8395-849X. E-mail: mulaevanm@kigiran.com
}

(C) KalmSC RAS, 2020
(C) Mulaeva N. M., 2020

\begin{abstract}
Introduction. In modern linguistics much attention is paid to the study of national/cultural features of functioning and semantics of emotive vocabulary. Still, Kalmyk emotive vocabulary has been no subject to any special research. Goals. The paper seeks to identify and classify lexicalsemantic groups of emotive verbs in texts of the Jangar epic, analyze functioning patterns of verbs denoting 'basic' emotions, namely: joy (Kalm. жирих 'be happy blissful', байрлх 'rejoice'), fear ( $ә x$ 'be afraid, frightened, have a dread of, fear', $u ч x$ 'be ashamed, embarrassed'), and one verb of external (physical) manifestation of emotions (инәх 'laugh'). Materials. The study analyzes emotive verbs traced in 28 Jangar texts recorded at different times (occasions) and either included in repertory cycles or once recited as separate songs. Results. The study reveals emotive verbs of the epic can be divided into six lexical and semantic groups. So, 'verbs of negative emotional states' are more frequently used than 'verbs of positive emotional states'. The latter are represented by two verbs, the verb жuphx definitely dominates throughout narratives examined, reflecting the state of utmost happiness that consists in peace, tranquility and well-being of the blessed Bumba in general; the verb байрлх is used to denote the short-term emotional state of joy of a particular character. As for 'verbs of negative emotional states', the verb əəx prevails in frequency. And it is revealed that the emotion of fear may occur for a number of reasons as follows: fear of failure to execute an order of the Bogdo; fear of breaking an oath; fear of name shaming. The paper observes only scarce cases of the use of verbs naming emotions of sadness (энлx), embarrassment (эмәх), and vexation ( $у н д x)$. The analyzed epic texts contain no emotive verbs that belong to semantic groups of fascination, love and hatred, worship or self-abasement.
\end{abstract}

Keywords: emotive verbs, emotional state, lexical and semantic groups, Kalmyk language, Epic of Jangar

Acknowledgements. The reported study was funded by government subsidy — project name 'Oral and Written Heritage of Mongolic Peoples of Russia, Mongolia and China: Cross-Border Traditions and Interactions' (state reg. no. AAAA-A19-119011490036-1).

For citation: Mulaeva N. M. Kalmyk Heroic Epic of Jangar: Emotive Verbs. Oriental Studies. 2020. Vol. 13(4): 1103-1120. (In Russ.). DOI: 10.22162/2619-0990-2020-50-4-1103-1120 


\section{Введение}

Как известно, различия в системе лексики языков мира зачастую определяются различиями в картине мира народов, которые говорят на данных языках. Изучение эмотивной лексики позволяет выявить национально-культурные характеристики определенного народа, которые так или иначе отражаются в коммуникативном поведении его представителей.

По мнению Л. Г. Бабенко, наибольшую роль в передаче эмоций играют глаголы, затем существительные и прилагательные, девяносто процентов эмотивной лексики составляют эти три класса слов. К лексическим средствам выражения эмоций относятся и эмотивные наречия, около десяти процентов эмотивной лексики составляют другие части речи, среди которых преобладают эмотивные междометия и частицы [Бабенко 1988: 155].

Актуальность исследования заключается в том, что эмотивная лексика в калмыцком языке практически не изучена. Цель исследования: выявить и классифицировать лексико-семантические группы эмотивных глаголов эпоса, рассмотреть функционирование некоторых эмотивных глаголов подробно.

Материалом для анализа являются эмотивные глаголы, зафиксированные в 28 текстах разновременных записей калмыцкого героического эпоса «Джангар», объединенных в репертуарные циклы или представленных отдельными песнями ${ }^{1}$.

\section{Эмотивные глаголы в эпосе «Джан- гар»}

В зависимости от того, какие положительные или отрицательные эмоциональные состояния называют эмотивные глаголы, представленные в текстах эпоса, мы разделили их на шесть лексико-семантических групп (ЛСГ). Следует отметить, что в ЛСГ не вошли глаголы, которые передают

${ }^{1}$ Исследование является продолжением работ, в которых апробируются материалы Толкового словаря языка калмыцкого героического эпоса «Джангар». См. подробно публикации: [Куканова 2016; Куканова 2018; Мулаева 2015; Мулаева 2017; и др.]. эмоциональное состояние животных: үргх 'пугаться' (12), жигшх перен. 'пугаться' (2), сүрдx ‘пугаться’ (1), өврx ‘недоумевать' (1) .

\section{1. ЛСГ «глаголы положительных эмо- циональных состояний» $(43)^{3}$}

К ЛСГ «глаголы положительных эмоциональных состояний» причисляют глаголы, с общим значением «испытывать положительное эмоциональное состояние». К положительным эмоциональным состояниям относят радость, гордость, удовлетворение, счастье, блаженство, чувство безопасности и др. [Довгаль, Шепелева 2015: 50].

Анализ текстов эпоса показал, что ЛСГ представлена двумя глаголами:

1) ж⿻肀 hx 'быть счастливым, блаженствовать' (39)

2) байрлх 'радоваться' (4).

\section{ж⿻ирих}

Глагол ж⿻р $x$ употребляется только по отношению к персонажам страны Бумбы. В значении 'быть счастливым' этот глагол употребляется в примерах, где нужно отразить, что делает счастливым простолюдина (перестать жить в нищете или взор прекрасноликой ханши). Во втором значении 'блаженствовать' встречается, как правило, в иллюстративных примерах вначале повествования каждой главы эпоса, чтобы отразить общее эмоциональное состояние наивысшего счастья, покоя и умиротворения), либо в конце, когда подводится итог повествования (обычно для передачи состояния наивысшего блаженства владыки богдо Джангара, богатырей, на пиру после очередной победы над грозным врагом) (см. табл. 1).

2 Эзндннь сүҮдрас үрги туульж йовна... ‘Тени хозяина пугаясь, брыкается он’ [БЦ: І].

Һархлань мөрнь сүрдәд, / Чичрәд бәәнд. 'Когда вышел, конь его был испуган, / Дрожал' [ОБ: I].

Ө hол дәврәд орад ирхнь, / Олн шовун / Оhтрһуд хальн чишкж⿻, / Өврн дахжс нисв. 'Когда через лес, что у реки, проскакали они, / Много птиц, / В небо с криком взмывая, / Недоумевая, полетели за ними' [БЦ: І].

${ }^{3}$ В скобках указана частототность словоупотреблений эмотивных глаголов в эпосе. 
Таблииа 1. Примеры употребления глагола ж⿻ир х в эпосе

[Table 1. Usage examples of the verb ж⿻uphx in epic narrative]

\begin{tabular}{|c|c|c|c|}
\hline $\begin{array}{l}\text { Значение } \\
\text { глагола ж⿻ир } x\end{array}$ & Иллюстративные примеры из эпоса & 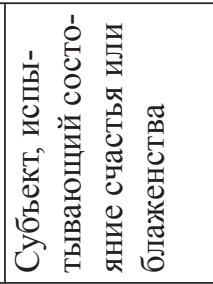 & 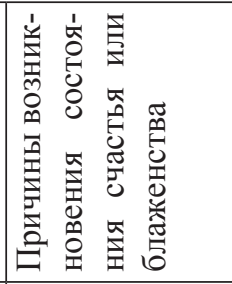 \\
\hline $\begin{array}{l}\text { 1) быть счаст- } \\
\text { ливым } \\
\text { (испытывать } \\
\text { счастье) }\end{array}$ & 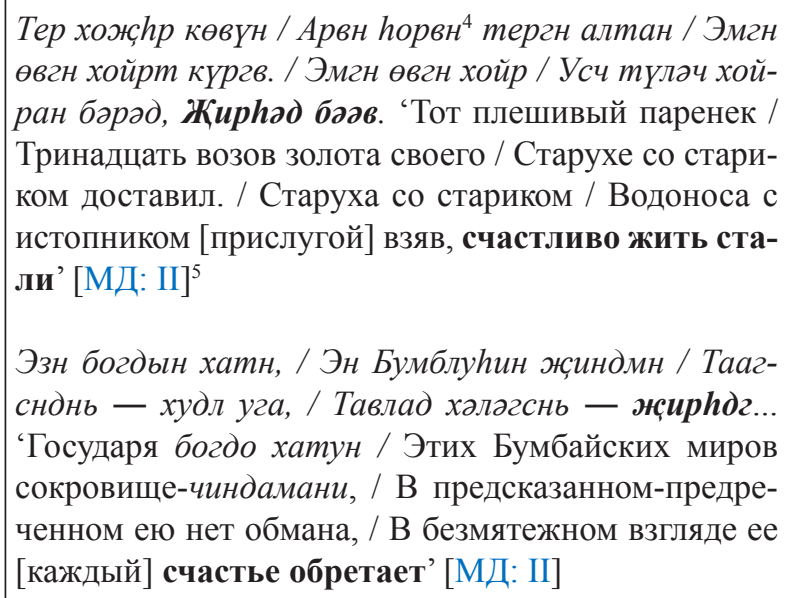 & $\begin{array}{l}\text { старуха со } \\
\text { стариком }\end{array}$ & $\begin{array}{l}\text { безмятежный } \\
\text { взгляд ханши } \\
\text { Ага-Шавдал }\end{array}$ \\
\hline $\begin{array}{l}\text { 2) блаженство- } \\
\text { вать (испыты- } \\
\text { вать чувство } \\
\text { блаженства, } \\
\text { большого сча- } \\
\text { стья) }\end{array}$ & 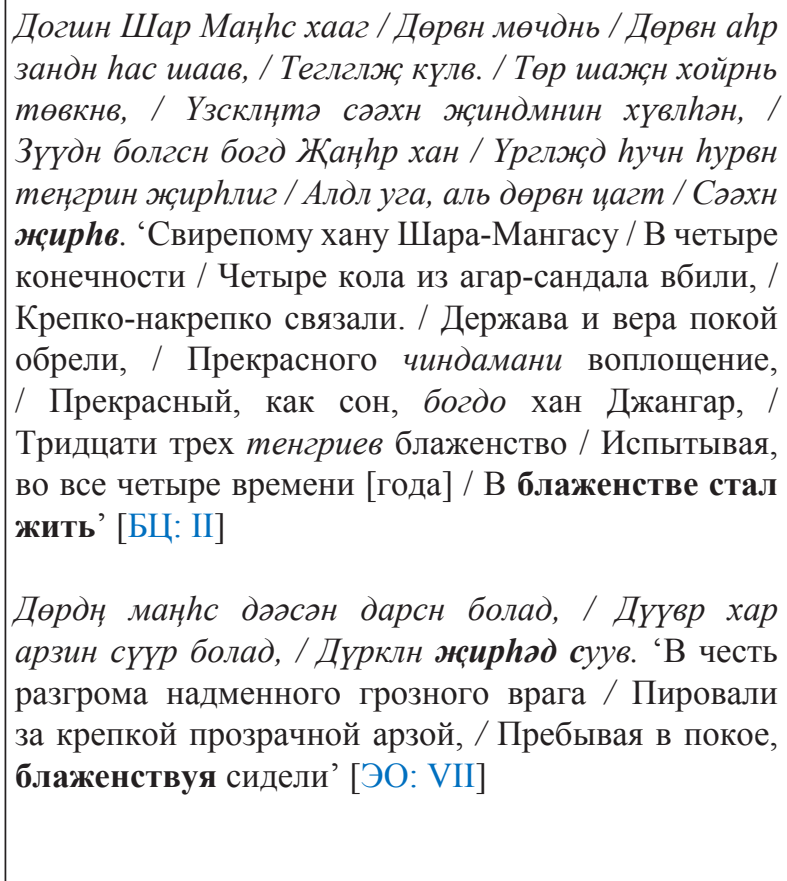 & $\begin{array}{l}\text { владыка } \\
\text { богдо } \\
\text { Джангар и } \\
\text { шесть тысяч } \\
\text { двенадцать } \\
\text { богатырей }\end{array}$ & \begin{tabular}{|l} 
разгром \\
надменного \\
грозного врага
\end{tabular} \\
\hline
\end{tabular}

${ }^{4}$ Һорвн 'три' — диал. дерб.; һурвн 'три' — лит. торг. [Пюрбеев 2015а: 99].

${ }^{5}$ Перевод текстов эпоса «Джангар» с калмыцкого языка на русский осуществлен авторами публикуемого многотомного «Свода калмыцкого фольклора», выполняемого Калмыцким научным центром РАН (ранее — КИГИ РАН), см. подробно: [Манджиева 2016; Манджиева 2017].

${ }^{6}$ Для толкования значений эмотивных глаголов были использованы Справочно-информационный портал «Грамота.pу» [Gramota.ru] и Электронный ресурс словарей русского языка, разработанный Институтом русского языка им. В. В. Виноградова РАН «Словари.ру» [Slovari.ru]. 


\begin{tabular}{|c|c|c|c|}
\hline & $\begin{array}{l}\text { Арднь, сәәдүдин нәр таргсн иагт, / Шилтә Зандн } \\
\text { Герл хатн / Тавн сара һазрт / Әрә багтмар бүҮр- } \\
\text { лгсн алвтыг / Зүс-зүсәрнь тоож, / Хоңһрин герт } \\
\text { орулжс һарһад, / Бурхн шажснь, нарна герл мет } \\
\text { мандлад, / Йиртмжсин төрнь, хад мет, батрад, / } \\
\text { жирhжс, дүргж, бәәдг мөн. 'Затем, когда кончился } \\
\text { пир сайдов, / Ханша Шилтэ Зандан Гэрэл / Поддан- } \\
\text { ных своих, / Едва размещавшихся на расстоянии } \\
\text { / пятимесячного пути, угощала, / В юрту Хонгора } \\
\text { их пригласив, / Вера бурханов, подобно солнцу, за- } \\
\text { сияла, / Правленье мирское, подобно скале, утвер- } \\
\text { дилось. / Блаженствуя, веселясь, они пребывают' } \\
\text { [ЭО: І] }\end{array}$ & подданные & $\begin{array}{l}\text { женитьба } \\
\text { богатыря } \\
\text { Хонгора }\end{array}$ \\
\hline
\end{tabular}

В текстах эпоса глагол ж⿻р一х в значении 'блаженствовать' употребляется в устойчивых формулах, можно заметить, что лексема теңзгр употребляется только в тех из них, где субъектом является владыка богдо Джангар, возможно, чтобы обозначить таким образом его небесное происхожение (см. табл. 2).

Таблица 2. Глагол ж⿻ир $x$ в устойчивых выражениях

[Table 2. The verb жcuphx in set phrases]

\begin{tabular}{|c|c|c|}
\hline Устойчивая формула & Перевод & $\begin{array}{l}\text { Субъект, испытывающий } \\
\text { чувство блаженства }\end{array}$ \\
\hline 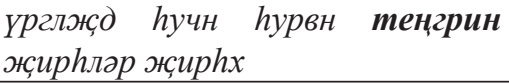 & $\begin{array}{l}\text { ‘всегда, тридцати трех тенгриев } \\
\text { блаженством блаженствовать’ }\end{array}$ & \multirow[t]{2}{*}{ владыка богдо Джангар } \\
\hline ахлгч теңгрин жсирһләр жсирһх & $\begin{array}{l}\text { 'главного из тенгриев блаженством } \\
\text { блаженствовать' }\end{array}$ & \\
\hline тогтун сәәхн ж⿻ириләр жсирих & $\begin{array}{l}\text { 'спокойным прекрасным } \\
\text { блаженством блаженствуют’ }\end{array}$ & \multirow{4}{*}{$\begin{array}{l}\text { владыка богдо Джангар и } \\
\text { шесть тысяч двенадцать } \\
\text { богатырей }\end{array}$} \\
\hline жчирһлин икәр жсирһх & $\begin{array}{l}\text { 'блаженством } \\
\text { блаженствовать' }\end{array}$ & \\
\hline дүрклн жирһх & 'пребывая в покое блаженствовать' & \\
\hline инәлдн ж⿻ирһх & ‘смеясь, блаженствовать' & \\
\hline жсирһх, дүргх & ‘блаженствовать, веселиться’ & подданные \\
\hline
\end{tabular}

\section{байрлх}

Для называния положительного эмоционального состояния радости в текстах эпоса служит глагол байрлх с семой эмотивности «испытывать кратковременную радость», который употребляется всего четыре раза, из них три отмечены в цикле песен из репертуара джангарчи Эляева Овлы и один - в песне Мукебена Басангова (см. табл. 3).

Таблица 3. Примеры употребления глагола байрлх в эпосе

[Table 3. Usage examples of the verb байрлx in epic narrative]

\begin{tabular}{|c|c|c|c|}
\hline $\begin{array}{c}\text { Значения } \\
\text { глагола } \\
\text { байрлх }\end{array}$ & Иллюстративные примеры из эпоса & $\begin{array}{c}\text { Субъект, } \\
\text { испытывающий } \\
\text { чувство радости }\end{array}$ & $\begin{array}{c}\text { Причины } \\
\text { возникновения } \\
\text { чувства радости }\end{array}$ \\
\hline $\begin{array}{l}\text { радовать- } \\
\text { ся }\end{array}$ & 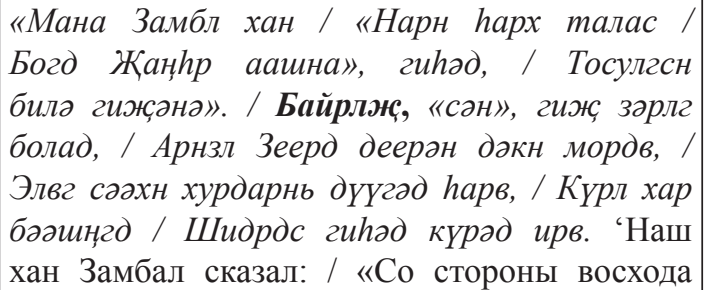 & $\begin{array}{l}\text { владыка богдо } \\
\text { Джангар хан }\end{array}$ & $\begin{array}{l}\text { испытывать чувство } \\
\text { радости по причи- } \\
\text { не того, что хан, } \\
\text { дочь которую хотят } \\
\text { засватать Хонгору, } \\
\text { настроен благожела- } \\
\text { тельно }\end{array}$ \\
\hline
\end{tabular}




\begin{tabular}{|c|c|c|}
\hline $\begin{array}{l}\text { солнца / Едет сюда богдо Джангар». / Нас } \\
\text { навстречу [тебе] он послал». / «Хорошо», } \\
\text { молвил, обрадовавшись, Джангар. / Снова } \\
\text { сел на аранзала Зеерде, / Быстро поскакал. / К } \\
\text { темно-бронзовому дворцу / Приблизился он’ } \\
\text { [ЭО: I] }\end{array}$ & & \\
\hline $\begin{array}{l}\text { Алдрсн төр шажсн хойран / Һар деерән авсн } \\
\text { мет байрлжс, / Эзн нойн богднь суудг... } \\
\text { 'Утраченные правление и веру, / Словно } \\
\text { [вновь] в свои руки взял, радуясь / Владыка } \\
\text { богдо-нойон, восседает' [ЭО: II] }\end{array}$ & $\begin{array}{l}\text { владыка богдо } \\
\text { Джангар хан }\end{array}$ & $\begin{array}{l}\text { испытывать чув- } \\
\text { ство радости при } \\
\text { сосредоточе н и } \\
\text { вновь в своих руках } \\
\text { правления и веры }\end{array}$ \\
\hline $\begin{array}{l}\text { Алтн Шарһ деерән һарад, / «Авһин келсн } \\
\text { hурвн дәәснәс / Һарув!», гижс санн байрлад, / } \\
\text { Ар Бумбан нутгиннь сәкүснд зальврад, / Дәкн } \\
\text { элвг сәәхн хурдарнь дүүгәд һарв. '[Мингъян] } \\
\text { вскочил на Алтан Шаргу, / «Избавился от } \\
\text { трех опасностей, о которых дядюшка мой } \\
\text { говорил», так подумав, обрадовавшись, / И, } \\
\text { помолившись духу-хранителю страны своей } \\
\text { Бумбы, / Дальше помчался стремглав’ [ЭО: } \\
\text { IX] }\end{array}$ & $\begin{array}{lr}\text { Мингъян, бога- } \\
\text { тырь } \\
\text { богдо } \\
\text { хана }\end{array}$ & $\begin{array}{l}\text { испытывать чув- } \\
\text { ство радости из-за } \\
\text { избавления от опас- } \\
\text { ности }\end{array}$ \\
\hline $\begin{array}{l}\text { Күмн күрч һарч чадшго / Уул санжслмч! гижс } \\
\text { санад, байрлад, / Хойр долан миңһн иергин } \\
\text { ардас һарад гүүлгвл. 'Оказывается, никто } \\
\text { не может подняться / На эту гору, подумав, } \\
\text { [Хонгор] обрадовался / И две недели мчался } \\
\text { за войском [врага]' [БМ: V] }\end{array}$ & $\begin{array}{l}\text { Хонгор, богатырь } \\
\text { владыки богдо } \\
\text { Джангара хана }\end{array}$ & $\begin{array}{l}\text { испытывать чув- } \\
\text { ство радости из-за } \\
\text { того, что никто не } \\
\text { сможет взобраться } \\
\text { на гору, где остав- } \\
\text { лен враг }\end{array}$ \\
\hline
\end{tabular}

2. ЛСГ «глаголы отрицательных эмоциональных состояний» (53)

К ЛСГ относятся глаголы, которые используются для обозначения отрицательных эмоциональных состояний, возникающих при неудовлетворении каких-либо потребностей. К отрицательным эмоци- ональным состояниям относятся печаль, горе, тревога, боязнь, ужас, гнев, неудовольствие, злоба, разочарование, отвращение, досада, ненависть и др. [Довгаль, Шепелева 2015: 51]. В текстах эпоса выявлено 11 глаголов данной группы, представленных в таблице 4 .

Таблица 4. Список глаголов отрицательных эмоциональных состояний

[Table 4. List of verbs denoting negative emotions]

\begin{tabular}{|c|c|c|}
\hline Глагол & Перевод & Частотность \\
\hline$\partial \partial x$ & 'бояться, пугаться, страшиться, опасаться’ & 19 \\
\hline$y \check{u} \partial x$ & 'печалиться' & 12 \\
\hline уурлх & 'гневаться, сердиться, злиться' & 7 \\
\hline$u \varphi x$ & 'стыдиться' & 4 \\
\hline hундx & 'обидеться’ & 4 \\
\hline өөлх & 'обидеться’ & 3 \\
\hline урньх & 'сердиться' & 3 \\
\hline сурдх & 'пугаться’ & 1 \\
\hline энлх & 'сокрушаться' & 1 \\
\hline эмәх & 'стесняться' & 1 \\
\hline hундх & 'досадовать' & 1 \\
\hline
\end{tabular}


Эмотивные глаголы $h y н д x$, өөлx употребляются в одном синонимическом ряду в сочетании с базовым эмотивом hундл 'обида' — для более эмоционального выражения переживаемой эмоции обиды как оскорбления: Намаг му деерм / Му кевүч, - гиһәд, / Һундад өөләд йовна. 'Плохонького меня / Еще более принизил, - говоря, / Обижаясь, чувствуя себя оскорбленным, идет' [ШД: ІІ]; Му деерм му кев билтәл, гиһәд, / Арнзлин хурдн Зеердд / Һундл һундад йовна. 'Мне, плохонькому, еще плохо делаете, говоря, / Резвому аранзалу Зеерде / Обиду высказывает он' [ШД: ІІ].

Эмоциональное состояние испуга антагониста, вызванное грозным видом исполина - богатыря Хонгора, отражено в следующем иллюстративном примере: Хоңһһрин әвриг үзчкәд, / Кинь күрәд уга бәәтл, / Һольнн улан иуснь / Өдрә һазрт циоонгрв, / Орклад, бәрклдд, сүрдљд унвл. 'Увидев исполина Хонгора, / Хотя [Хонгор] не коснулся его [копьем], / [У Нарни Герела] полилась кровь из горла / На расстояние дневной езды, / [Нарни Герел] крича, вопя, испугавшись, упал' [БМ: V].

Глагол энлх эмоцию печали передает в значении 'сокрушаться (сильно огорчаться, печалиться)': Көвүг таньл уга, / «Көөрк Жаңһриг алжс оркад, / Арнзлынь унжс йовна!» гиһдд, / Энләд, ууляд бәәв. 'Мальчика не узнав, / «[Нашего] бедного Джангара убив, / На аранзале его разъезжает!», говоря, / Сокрушались, плакали' [МД: III].

Эмоция смущения передается эмотивом эмәх: Һунн наста көвү авч орхдан, / Энугин олн сәәдүдәс эмәһәд, / Хойр хонгт орл уга, yxa myң̧hаһад бәәв. '[Нойон Кюкен Цаган] трехлетнего мальчика с собой привести, / Перед многочисленными сайдами постеснявшись, / Двое суток не входя [во дворец] в раздумье стоял' [ЭО: IV].

Эмотивный глагол hyндx употребляется в значении 'досадовать' с семой эмотивности «испытывать чувство досады, вызванное обидой», которое в иллюстративном примере усиливается сочетанием аман бәрх 'рот прикрыть': Арднь тавад зун берәд, күҮкд, / Аман бәрн һундад: / «Бум ирв чигн / Буил уга бәргддг эс билү? 'Пятьсот молодок и девиц / Прикрыли рты, досадуя: / «Сто тысяч [человек] проезжало [здесь] / Разве противились, оказавшись у нас»' [ЭО: IX].

\section{$\partial \partial x$}

В эпосе отмечено 101 словоупотребление глагольной формы әəx, из них 72 входит в состав имени хана-антагониста (Әәх Маңһc хан 'Грозный хан Мангна'), 10 употребляются как причастная форма в значениях 'устрашающий, грозный' (әәх бий 'устрашающий вид', әәх мет баатрмуд 'грозные богатыри [Шара-Мангаса]'). Таким образом, проанализировано 19 иллюстративных примеров, где встречается эмотивный глагол әәх; особенности его функционирования отражены в таблицах 5,6 . В таблице 5 обозначены проявления значений глагола әәх в иллюстративных примерах, где речь идет о Бумбайских богатырях, в таблице 6 - об антагонистах.

Таблица 5. Семантика глагола әәх, называющего эмоции страха богатырей Бумбы

[Table 5. Semantics of the verb zәx, which calls the emotions of fear bogatyrs Bumba]

\begin{tabular}{|c|c|c|c|}
\hline $\begin{array}{c}\text { Значения } \\
\text { глагола әәх }\end{array}$ & Иллюстративные примеры из эпоса & $\begin{array}{c}\text { Субъект, } \\
\text { испытывающий } \\
\text { чувство страха }\end{array}$ & $\begin{array}{c}\text { Причины } \\
\text { возникновения } \\
\text { страха }\end{array}$ \\
\hline 1) бояться & 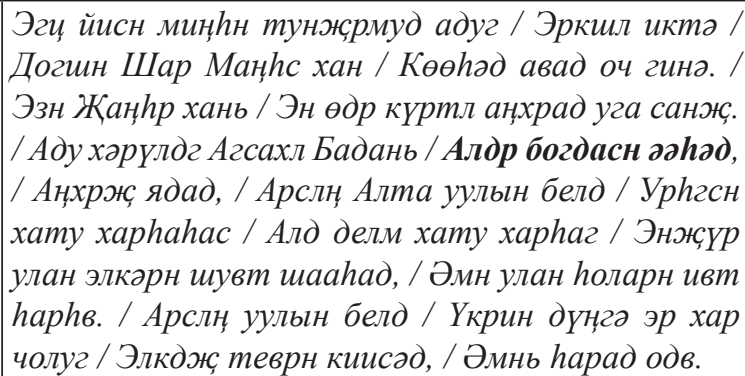 & $\begin{array}{l}\text { табунщик } \\
\text { богдо Джангара }\end{array}$ & $\begin{array}{l}\text { и с п ы т ы в а т ь } \\
\text { «б л а го го в е й - } \\
\text { ный» страх пе- } \\
\text { ред богдо Джан- } \\
\text { гаром }\end{array}$ \\
\hline
\end{tabular}




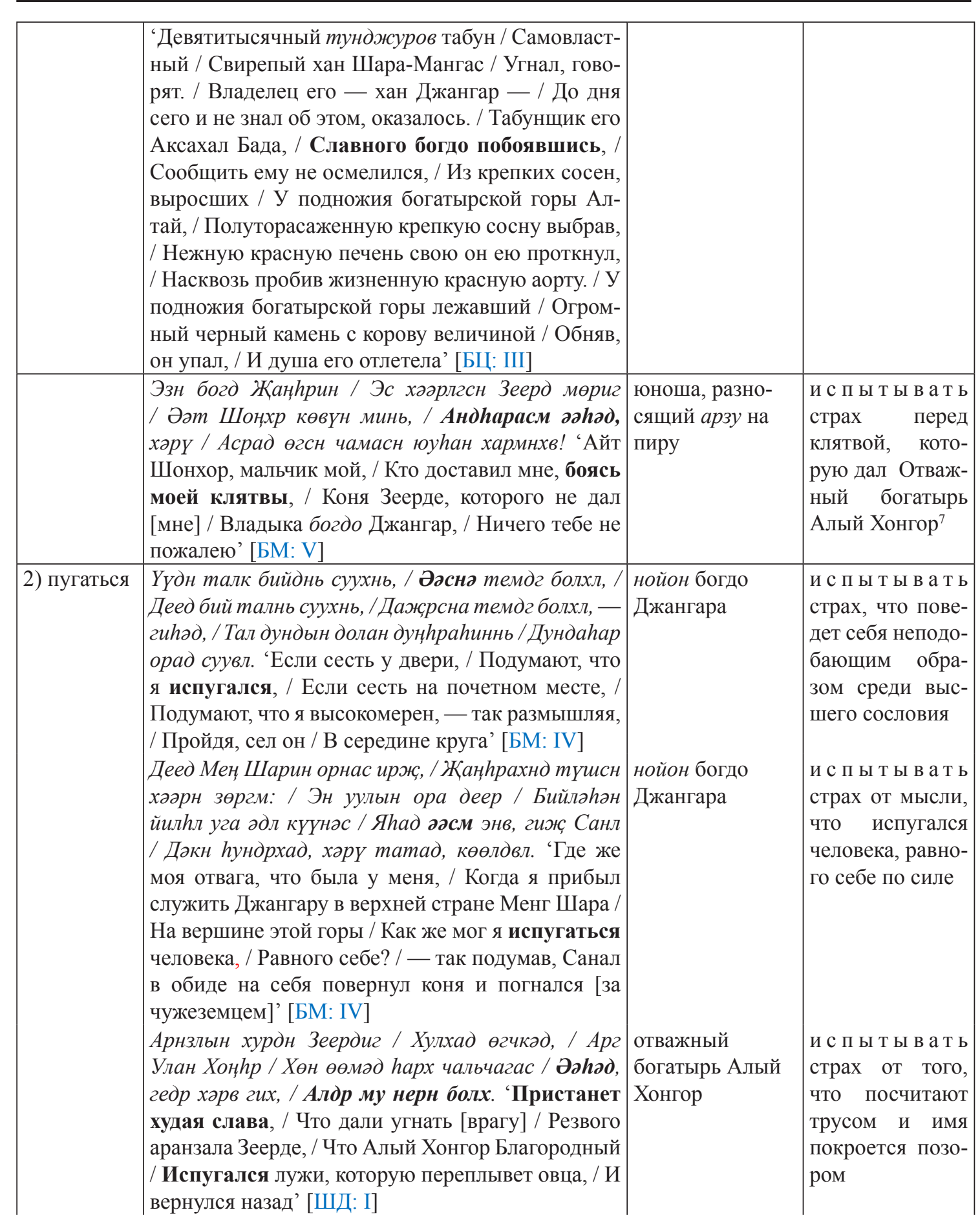

7 Эн хойр хаана төләд / Эн туг мөрн хойриг хармна йовж⿻ / Арг Улан Хоңһһp / Андһартан күрлго бәәх уга бишийе, / Эн тугин ора деер / Хавсан хадрулж, шарулжс бәәхин орчд / Эн туг мөрн хойриг өгслчн! - гиһәд, — / ХәрҮ эргәд ирв, — гинәл. '«Из-за этих двух ханов / Пожалел я знамя и коня, / Отважный Алый Хонгор / Исполнит непременно клятву свою. / И, чем жариться пронзенным навершием знамени, / Чем остаться без ребер, / Отдам-ка ему знамя и коня», подумав, / Повернул коня назад, приехал' [БМ: V]. 


\begin{tabular}{|c|c|c|c|}
\hline & 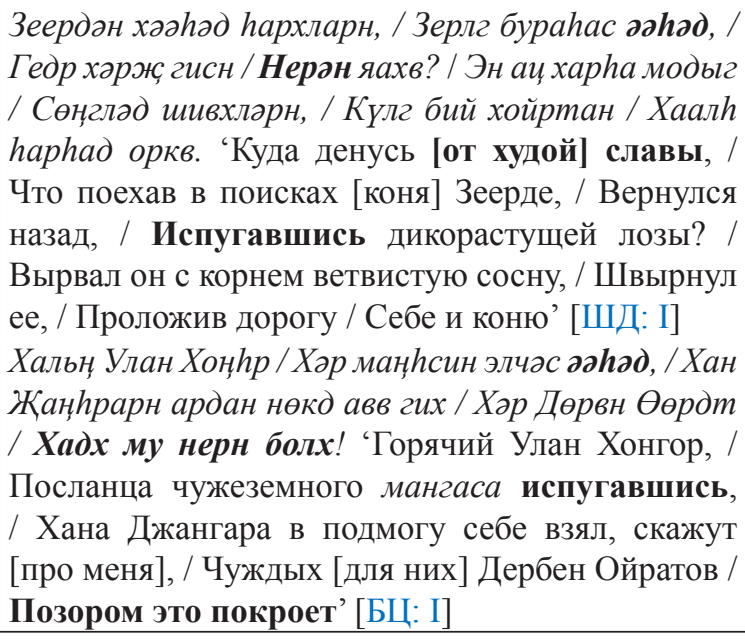 & $\begin{array}{l}\text { отважный } \\
\text { богатырь Алый } \\
\text { Хонгор } \\
\\
\\
\text { отважный бога- } \\
\text { тырь Алый Хон- } \\
\text { гор }\end{array}$ & \\
\hline & 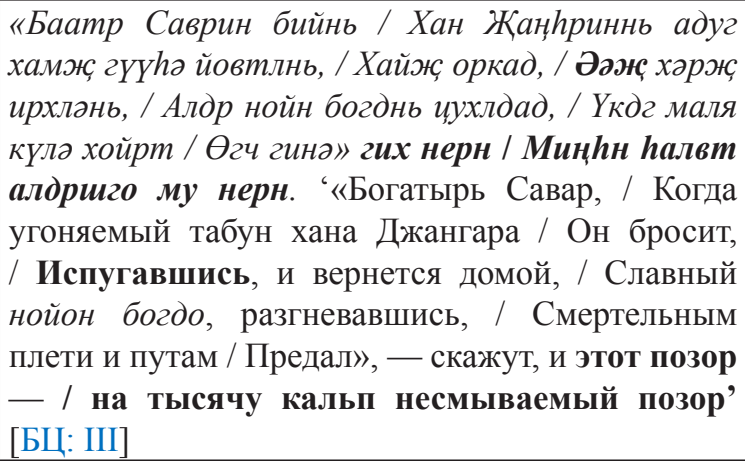 & богатырь Савар & \\
\hline & 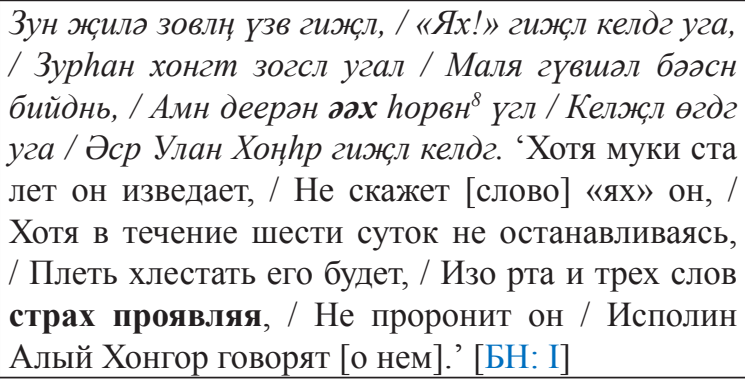 & $\begin{array}{l}\text { отважный } \\
\text { богатырь Алый } \\
\text { Хонгор }\end{array}$ & $\begin{array}{l}\text { и с п ы т ы в а т ь } \\
\text { страх от того, } \\
\text { что не проявит } \\
\text { свою выдержку }\end{array}$ \\
\hline $\begin{array}{l}\text { 3) опасать- } \\
\text { ся }\end{array}$ & 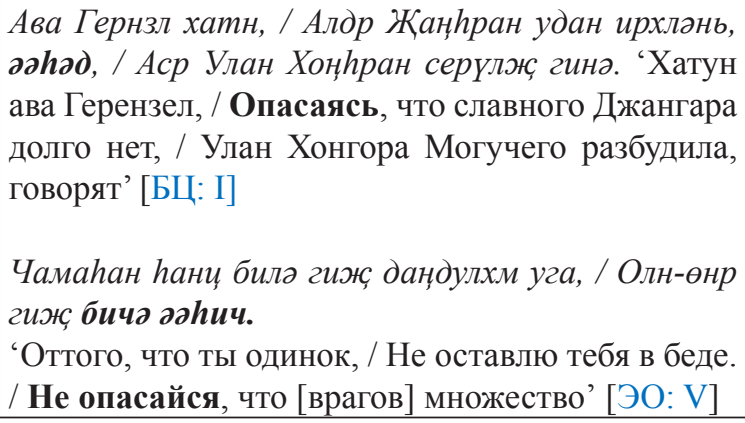 & $\begin{array}{l}\text { супруга } \\
\text { богатыря } \\
\text { Хонгора } \\
\\
\text { богдо Джангар }\end{array}$ & $\begin{array}{l}\text { и с п ы ты в а ть } \\
\text { страх (тревогу, } \\
\text { беспокойство) } \\
\text { за ближнего }\end{array}$ \\
\hline
\end{tabular}

Для бумбайских богатырей превыше всего честь и достоинство, почитание своего предводителя - богдо Джангара, нерушимость данной клятвы, проявление безудержной смелости: Өмндсмидн тосуд ирх дәәсн / Өргн ик нигт билә гиж, / Әәжс манд нөкдән ардан хәләх / Нег күн уга биший! 'Нет среди нас ни одного человека, / Испугавшись, оглядывающегося назад, прося помощи, / Хотя врагов, идущих навстречу / Бесчисленное множество' [БM: I].

Чувство страха возникает у богатырей в мыслях лишь на мгновение, а затем они

${ }^{8}$ Һорвн 'три' - диал. дерб.; һурвн 'три' — лит. торг. [Пюрбеев 2015a: 99]. 
бесстрашно бросаются на врага или преодолевают препятствие в пути.

Из-за проявления своего страха богатырь мог подвергнуться наказанию: Хә $\mathrm{x} a$ ани нег көвүн ирәд келгсн / Хойр амн үгас әəhəd бадихасн таднд / Хөөннь минь засг хату болх! гиж келәд, / Арг Зууһин Улан Хоңһр / Мордад һарад одвл. 'Вам, кто испугался двух слов парня, / Посланца чужезем- ного хана, / Наказание мое будет в последующем страшным! - сказав, / Отважный Алый Хонгор вскочил на коня / И отправился [в путь]' [БМ: V].

Глагол әәх в иллюстративных примерах, где речь идет об антагонистах, малоупотребителен, и те немногие примеры показывают, что для них самое ценное - это сохранить свои жизни (см. табл. 6).

Таблиия 6. Семантика глагола дәх, называющего эмоции страха антагонистов

[Table 6. Semantics of the verb zәx, which names the emotions of fear of antagonists]

\begin{tabular}{|c|c|c|c|}
\hline $\begin{array}{c}\text { Значения } \\
\text { глагола әәх }\end{array}$ & Иллюстративные примеры из эпоса & $\begin{array}{c}\text { Субъект, } \\
\text { испытывающий } \\
\text { чувство страха }\end{array}$ & $\begin{array}{c}\text { Причины } \\
\text { возникновения } \\
\text { страха }\end{array}$ \\
\hline 1) опасаться & $\begin{array}{l}\text { Хаани зергд шалдг / Нәәмн миңһн баатр / Мөңък } \\
\text { дөрвн иагт / Хааһан дундан авад, / Манн гетәд } \\
\text { суудг болна, / Терс дөрвн Үзгәс / Хар болх гижж, } \\
\text { / Әәдг болна, / Теңци уга Заңбу Тивин хаадудас } \\
\text { / Әмндм хор болх гижс, / Әәдг болна. 'При хане } \\
\text { самом — избранные / Восемь тысяч богатырей, } \\
\text { / В вечные четыре времени [года] / Окружив его } \\
\text { собой, / Охраняют. / Как бы вражеские четыре } \\
\text { стороны / Зла ему не причинили - / Этого он } \\
\text { опасается, / Как бы ханы Замбутива, равных } \\
\text { которым нет, / Жизни его не лишили - / Этого } \\
\text { он опасается' [БЦ: ІІ] }\end{array}$ & хан-антагонист & $\begin{array}{l}\text { испытывать } \\
\text { чувство страха } \\
\text { за свою жизнь }\end{array}$ \\
\hline $\begin{array}{l}\text { 2) стра- } \\
\text { шиться }\end{array}$ & $\begin{array}{l}\text { Өмнк дәәни баатрмуднь / Түрүн нааран мордхдан } \\
\text { / Эн Гүмбән шорас әәхләрн, / Догшн номар } \\
\text { гүрмән кегүлдг гинд. 'Богатыри вражеские всегда } \\
\text { / Перед тем, как сразиться с ним, / Этого штыка } \\
\text { Гюмбе страшась, / Молебен о спасении от него } \\
\text { заказывают, говорят' [БЦ: I] }\end{array}$ & $\begin{array}{l}\text { богатыри-анта- } \\
\text { гонисты }\end{array}$ & $\begin{array}{l}\text { испытывать } \\
\text { леденящий } \\
\text { страх перед } \\
\text { грозным } \\
\text { оружием } \\
\text { Бумбайского } \\
\text { богатыря }\end{array}$ \\
\hline
\end{tabular}

\section{uyx}

Включение глаголов әәх 'бояться, пугаться, опасаться, страшиться' и глагола ичх 'стыдиться' в одну семантическую группу обоснованно, это подверждается и иллюстративными примерами эпоса, где чувство стыда и страха проявляются одновременно: Эзн богд Жаңһһннь / Алтн Күнкә Чеежсасн / Суржс бәәдг болнал: / Шар Кермн гидг хаана / Хоорнд йовх хаалһд / Әәх, ичх юмн баәхлә,
/ Теругинь Хоңһрт зааһад өгит, гивл. 'У мудреца Алтан Чеджи / Спрашивает: / На пути / В [страну] Шара Кермен хана / Чего бояться, стыдиться, / Это подскажите Хонгору, говорит' [БМ: III].

Анализ малоупотребительного глагола ичx (4) в эпосе выявил, что возникновение чувства стыда совпадает с одной из причин возникновения чувства страха - боязнью опозорить имя (нернәс ичх) (см. табл. 7). 
Таблица 7. Примеры употребления глагола ичх в эпосе

[Table 7. Usage examples of the verb $u u_{x}$ in epic narrative]

\begin{tabular}{|c|c|c|c|}
\hline $\begin{array}{c}\text { Значения } \\
\text { глагола } u ч x\end{array}$ & Иллюстративные примеры из эпоса & $\begin{array}{c}\text { Субъект, ис- } \\
\text { пытывающий } \\
\text { чувство стыда }\end{array}$ & $\begin{array}{c}\text { Причины } \\
\text { возникновения } \\
\text { чувства стыда }\end{array}$ \\
\hline $\begin{array}{l}\text { стыдиться } \\
\text { (испыты- } \\
\text { вать чувство } \\
\text { стыда) }\end{array}$ & 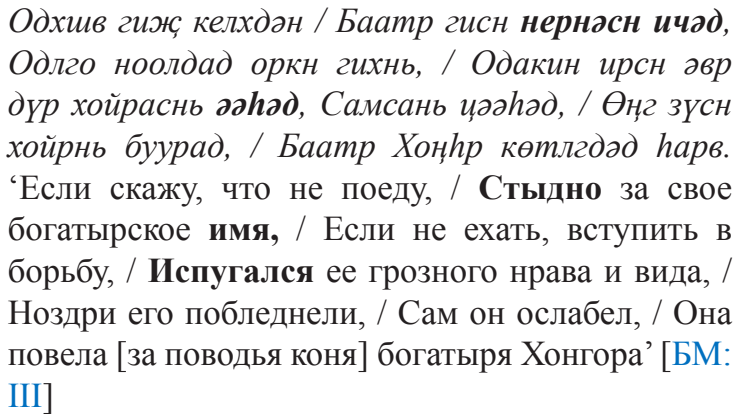 & $\begin{array}{l}\text { богатырь Хон- } \\
\text { гор }\end{array}$ & $\begin{array}{l}\text { страх опозорить } \\
\text { богатырское имя }\end{array}$ \\
\hline & $\begin{array}{l}\text { Арнзльлн хурдн Зеердиг / Хулхад өгчкәд, / Алдр } \\
\text { богд Жаңһра боднгуд / Хуһар хәәжс гисн / } \\
\text { Нернәснь ичжсәнәв. 'Дав [возможность врагу] } \\
\text { угнать / Резвого аранзала Зеерде, / Я стыжусь } \\
\text { теперь молвы о том, что скажут: / «Ищут [коня] } \\
\text { / Все вепри славного богдо Джангара»’ [ШД: I] } \\
\text { Уралан орхла, / Эн хан намаг алх, / Ардагщан } \\
\text { хәрхлд, / Алдр нойн богд Жаңһp / Намаг ичәх, } \\
\text { 'Если поеду вперед, / Убьет меня этот хан. / Если } \\
\text { обратно вернусь, / Славный Джангар-нойон- } \\
\text { богдо / Меня пристыдит' [ЭО: ІІІ] }\end{array}$ & $\begin{array}{l}\text { богатырь Хон- } \\
\text { гор }\end{array}$ & 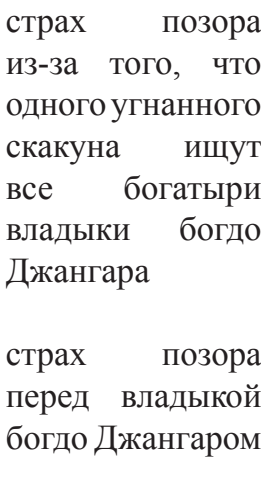 \\
\hline
\end{tabular}

\section{3. ЛСГ «Глаголы нейтральных} эмоциональных состояний» (3)

К лексемам, называющим нейтральные эмоциональные состояния, относят глаголы, которые не связаны с переживанием удовольствия или неудовольствия, к нейтральным эмоциям относятся удивление, изумление [Довгаль, Шепелева 2015: 51].

В текстах эпоса нейтральные эмоциональные состояния удивления и изумления называются глаголом өврx:

1) өврх 'удивиться' (2);

2) өврх ‘изумляться' (1).

Глагол өврх 'удивляться' содержит сему эмотивности 'испытывать чувство удивления', в контексте глагол өврх 'удивляться' употребляется в сочетании с глаголом внешнего (физического) проявления эмоций индх: Эмгн, юунд инәв чи? / - Эн унтгсн хойр көвү өврәд, / Инджс бадндв 'Старуха, чему ты смеялась? / - Этим заснувшим двум юнцам удивляясь, / Смеюсь' [МД: II]; Деед Бумбин орни зүүдн болгсн / Жаңһрар махан чанулжч оркад, / Унтад баддг хойр көвү өврәд, / Инәһәд баәнав. 'В вышних Бумбайских странах сновидением ставшего, / [Самого] Джангара мясо варить заставившим, / Спящим двоим юнцам удивляясь, / Смеюсь я’ [МД: II].

Глагол өврх в значении 'изумляться' содержит сему эмотивности «очень сильно удивиться». Из контекста видно, что персонажи эпоса испытывают эмоциональное состояние крайнего изумления при внезапном преображении главного героя эпоса и его скакуна: Алтн Гүргу хаани өргәд / Нирглдгсн бәәдг. / ТҮдҮ аңхн дунд / Баатр Жаңһһр / Мөн кевтән тохрв. / Арнзл Зеерд / Мөн кевтан тохрв. / Алтн Гүргу хаани орн / Жанһр Зеерд хойриг / өврәд бәәв. 'Алтан Гюргю хана во дворце / Шумно пируют-веселятся. / И в это самое время / Богатырь Джангар / Истинный свой облик принял. / Аранзал Зеерде / Истинный свой облик принял. / Алтан Гюргю хана народ / На Джангара и Зеерде, / Изумляясь, взирал' [МД: ІІ].

\section{4. ЛСГ «Глаголы положительного эмоционального отношения» (4)}

Семантическим признаком ЛСГ «глаголы положительного эмоционального от- 
ношения» является наличие семы, указывающей на направленность положительной эмоции (восхищение, любовь, интерес, уважение, доверие и др.) на какой-либо объект. В эпосе зафиксировано два глагола, относящихся к ЛСГ «глаголы положительного эмоционального отношения»:

1) доталх 'дорожить, нежно относиться' (3);

2) maасx 'нравиться’ (1).

Глагол доталх 'дорожить, нежно относиться’ с семой эмотивности «испытывать нежность» употребляется для демонстрации чувства особой привязанности к соратнику-богатырю: Әмн мет өврлгсн / Гергнәсн доталдг эс билү би? 'Как жизнь оберегаемой / Жены своей ближе считал я тебя, не так ли?' [БЦ: I]; Ончлгсн һанияхн көвүнәсн / Доталдг эс билү би? 'Любимого единственного сына своего / Ближе считал я тебя, не так ли?' [БЦ: I]; Догшн тәрнтә Шар Ширмин хаани / Доталюс түщәдг бодн,, 'Для обладателя сильных заклинаний хана Шара Ширмина, / Он дороже всех вепрь-[витязь]' [ШД: ІІІ].

Глагол maacx 'нравиться' употребляется в значении «испытывать чувство расположения, симпатии к кому-л.» ${ }^{9}$. В текстах эпоса этот глагол употребляется один раз, при описании момента, когда богатырю пришло время жениться и он обязан выбрать девушку, в контексте не говорится о каких-либо эмоциональных переживаниях персонажа: Көвүн, көвүн! / Мини алвт эргж, / Нег күүк хәләжскел, - гив. / Шар Ширмин хан / Адуни ах зах алг мөр / Тохулад өгв. / Унад һарв. / Арслң гидг боднзгин / Күүк таacad ирв. / Күүкнд келәд, 'Сынок, сынок! / Объедешь мои владения, / Присмотри [себе] девушку и скажи [мне], - сказал [хан]. / Хан Шара Ширмин / Велел оседлать ему / Главного в табуне пегого коня. / Сел он на коня и отправился. / Возвратился он и сказал [хану], / Что ему понравилась дочь богатыря Арсланга. / Сосватали девушку' [ШД: V].

9 В другом примере глагол maacx употребляется без эмотивной окраски: Көвүг мөр довтлулжс чадх гижс таасв. '[Хонгор] решил, что мальчик сможет скакать на лошади’ [ШД: II].

\section{5. ЛСГ «глаголы отрицательного эмоционального отношения» (2)}

Семантическим признаком ЛСГ «глаголы отрицательного эмоционального отношения» является наличие семы, указывающей на направленность отрицательной эмоции (ненависть, презрение, зависть, жалость, зависть, возмущение) на какой-л. объект.

ЛСГ представлена двумя глаголами, которые выражают не прямые, а переносные значения:

1) hазалх 'перен. пренебрегать' (1);

2) өнзгәх 'перен. завидовать' (1).

Глагол hазалх ${ }^{10}$ употребляется в переносном значении 'пренебрегать (меньше любить)', сема эмотивности «испытывать чувство презрения, высокомерия» усиливается антонимом доталх: Эврәннь әмн улан һол / Аср Улан Хоңһһр хоюлан / Алькинь доmaлx би, / Алькинь hазалх би? 'Моя собственная жизнь / Или Улан Хонгора Могучего [жизнь] / Какой из них дорожить должен я / Какой из них пренебречь должен я?' [БЦ: I].

Глагол өңзгәх11 'перен. завидовать' употребляется в контексте в значении «испытывать чувство досады, раздражения, вызванное удачей, благополучием другого, сопровождаемое желанием обладать тем, что есть у другого»: Олн таниг иуглулсн / Алдр сәәхн нер мини / Дегд холд одад, / Нанд күн өцгəһдљ бәәнд. 'Всех вас собравшая / Слава моего доброго имени / Очень далеко разнеслась, / Враг испытывает чувство зависти' [ЭО: VII].

\section{6. ЛСГ «глаголы внешнего} (физического) проявления эмоций» (70)

Некоторые исследователи отдельно выделяют ЛСГ глаголов «внешнего (физического) проявления эмоций» с категориально-лексической семой - «выражать во внешности, жесте эмоциональное состояние, отношение» [Бабенко 1989: 72].

В текстах эпоса к ЛСГ «глаголов внешнего (физического) проявления эмоций»

${ }^{10}$ Һазалx 'считаться чужим, чуждаться; различать; перен. меньше любить' [КРС 1977: 152].

${ }^{11} Ө$ нзгәх 'нависать над чем-л.; смотреть сверху; высовываться, выдаваться вперед; надеяться на получение чего-л.' [КРС 1977: 418]. 
относятся глаголы уульх, индх, которые выражают и положительные и отрицательные эмоции:

1) уульх 'плакать' (48);

2) инәх 'смеяться' (22).

Глагол уульх 'плакать' в значении «под действием эмоций проливать слезы» употребляется в устойчивых формулах, которые усиливают эмоции печали или радости, выражаемые этим глаголом:

1) аршан хар нольмсан унһан уульх 'как аршан, чистые слезы роняя, плакать';

2) аршан хар нольмсан цุацнн уульв 'как аршан, чистые слезы разбрызгивая, плакать';

3) богшурһан дүнцгә мөндр хар нульмсан асхрулад, уульх 'с воробья величиной град прозрачных слез проливая, плакать';

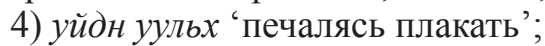

5) энләд уульх 'печалясь плакать';

6) уульх, унжсх 'плакать, всхлипывать';

7) $х ә р у$ хәләһәд уульх 'отвернувшись в сторону, плакать';

8) теврлдн уульх 'обнимаясь плакать'.

Этот глагол при передаче положительных и отрицательных эмоций употребляется в сочетании с другими глаголами, которые помогают глубже отобразить эмоциональное состояние персонажа. Например, эмоция печали передается следующим образом: Иим ahy ик күчтә күүкиг / Би күрч яһжс үзхмбви, — гиһәд, / Анчн нерто зүркнь / Әәвлхә дотрнь салдисн, / Арвн ичаһан хурһнь / Ханцин дотрнь салдисн, / Аршан хар нульмсан / Асхрулад ууляд сууна. 'С таким огромным, сильным войском девушку / Как же я доберусь, увижу? - так сказав, / Горячее сердце его / Ослабло в груди, / Десять белых пальцев его / В рукаве ослабли, / Как аршан прозрачные слезы, / Роняя плачет сидит' [ШД: II].

Эмоциональное состояние радости обычно передается сочетанием ууляд тевр$л д x$ 'плача обниматься': Хоңһр Жаңһһр хойр / Таш бун ууляд, / Теврлдәд $Y$-хә болв. 'Хонгор и Джангар / Тут же спешились прослезились, / Обнялись, начали вести задушевную беседу’ [ЭО: I].

\section{uнวx}

В настоящее время исследователи проявляют интерес к изучению смеховой культуры монголов, в том числе и калмыков [Пюрбеев 2015б; и др.]. В текстах эпоса выявлены разные формы смеха, которые обозначаются словесными формулами и звукоподражаниями:

1) aщ̧hp-ац̧hр инәх 'смеяться, широко открывая рот';

2) марзиз-марзи инәх 'широко улыбаясь, смеяться';

3) Һуян ташн, һолһаһан тасртл инәх 'шлепнув по бедру, смеяться до коликов ${ }^{12}$ ';

4) индлдн жсирhx 'смеясь, блаженствовать';

5) тачкнжс инәх 'громогласно смеяться';

6) өвдгән изокжс, хәәкржс индх 'шлепнув по коленям, громко смеяться';

7) аман бәрәд бөгшәд, инәх 'рот прикрывая, трястись от смеха'.

Причинами смеха могут являться положительные эмоции по причине радости либо такие негативные эмоции, как насмешка над богатырем (см. табл. 8).

Таблииза 8. Примеры употребления глагола инәх в эпосе

[Table 8. Usage examples of the verb инәх in epic narrative]

\begin{tabular}{|c|c|c|c|}
\hline $\begin{array}{c}\text { Значения } \\
\text { глагола } и н ә x \\
\text { 'смеяться' }\end{array}$ & Иллюстративные примеры из эпоса & \begin{tabular}{|c|} 
Субъект, у \\
которого что-то \\
вызвало смех \\
\end{tabular} & $\begin{array}{c}\text { Причины } \\
\text { возникновения } \\
\text { смеха } \\
\end{array}$ \\
\hline $\begin{array}{l}\text { 1) издавать } \\
\text { смех }\end{array}$ & $\begin{array}{l}\text { Алдрсн төр шажсн хойран / Һар деерән авгсн } \\
\text { мет, байрлжс, / Эзн нойн богднь суудг , / Эңзин } \\
\text { олн сәәдүдтәһән / Инәлдн жсирһәд суудг. } \\
\text { ‘Владыка богдо-нойон [Джангар], радуясь вос- } \\
\text { седал, / Словно [вновь] в свои руки взял / Утра- } \\
\text { ченные правление и веру. / Со всеми сайдами } \\
\text { своими / Веселясь, блаженствовал он’ [ЭО: II] }\end{array}$ & 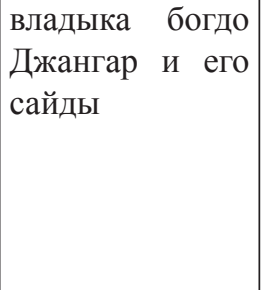 & $\begin{array}{l}\text { радость от того, } \\
\text { что правление } \\
\text { и вера верну- } \\
\text { лись вновь к } \\
\text { владыке богдо } \\
\text { Джангару }\end{array}$ \\
\hline
\end{tabular}

12 Устойчивое выражение hолhаһан тасртл инәх 'смеяться до коликов' (досл. 'смеяться, пока не оборвется толстая кишка') относится к разряду фразеологизмов [Пюрбеев 2015a: 129]. 


\begin{tabular}{|c|c|c|c|}
\hline & $\begin{array}{l}\text { Пө-ө! Хәрин хаадудт хәлдж,, / Халун ик үгиг } \\
\text { келдг бодң / Боднцуд дотрм / Бәәдмн болна } \\
\text { билтәл! гижс, / Хан өвдгән ицокж, / Хәәкржс, инәжс } \\
\text { бдәдг болнал. 'Да-а! Есть, оказывается, / Среди } \\
\text { моих вепрей / Богатырь, способный сказать в } \\
\text { лицо хану-чужеземцу / Такие горячие слова! / } \\
\text { Шлепнув по коленям, / Засмеялся громко хан } \\
\text { [Джангар]' [БМ: V]. }\end{array}$ & $\begin{array}{ll}\text { владыка } & \text { богдо } \\
\text { Джангар } & \end{array}$ & $\begin{array}{l}\text { радость вла- } \\
\text { дыки богдо } \\
\text { Джангара от } \\
\text { того, что в под- } \\
\text { чинении у него } \\
\text { достойный бо- } \\
\text { гатырь }\end{array}$ \\
\hline & 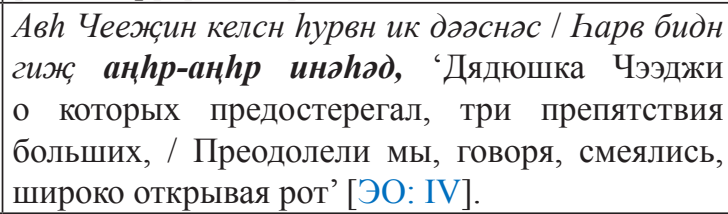 & $\begin{array}{l}\text { богатыри богдо } \\
\text { Джангара }\end{array}$ & $\begin{array}{l}\text { радость от } \\
\text { преодоления } \\
\text { препятствий в } \\
\text { пути }\end{array}$ \\
\hline $\begin{array}{l}\text { 2) насмехать- } \\
\text { ся, издевать- } \\
\text { ся над кем-, } \\
\text { чем-л. }\end{array}$ & $\begin{array}{l}\text { ТҮҮнлә бийән дүнцүлдг / Эргу юмнвч? гиһдd, } \\
\text { hуян ташн, / Һолһаһан хаһртл инәв. 'Какой же } \\
\text { ты глупец, что равняешь его с собою, / Сказал } \\
\text { [Санал], / Шлепнув себя по бедрам, / Смеялся до } \\
\text { колик в животе' [ЭО: V] }\end{array}$ & $\begin{array}{lr}\text { богатырь } & \text { вла- } \\
\text { дыки } & \text { богдо } \\
\text { Джангара } & \end{array}$ & $\begin{array}{l}\text { насмешка над } \\
\text { б о га т ы е м, } \\
\text { который срав- } \\
\text { нивает себя с } \\
\text { одним из бога- } \\
\text { тырей владыки } \\
\text { богдо Джанга- } \\
\text { ра }\end{array}$ \\
\hline
\end{tabular}

В зависимости от положительных или глагол, их можно классифицировать по сеотрицательных эмоциональных состояний, мантическим подгруппам (радость, любовь, которые передает тот или иной эмотивный интерес, уважение и т. д.) (см. табл. 9).

Таблииа 9. Семантические подгруппы и частотность эмотивных глаголов

[Table 9. Semantic subgroups (subclusters) and frequency use of emotive verbs]

\begin{tabular}{|c|c|c|c|}
\hline № & $\begin{array}{c}\text { Семантические } \\
\text { подгруппы }\end{array}$ & Эмотивные глаголы & $\begin{array}{c}\text { Общее } \\
\text { количество } \\
\text { употреблений }\end{array}$ \\
\hline 1. & радость & $\begin{array}{l}\text { жстир ‘ ‘быть счастливым, блаженствовать’ (39) } \\
\text { байрлх ‘радоваться’ (4) }\end{array}$ & 43 \\
\hline 2. & любовь & - & \\
\hline 3. & интерес / влечение & maасx 'нравиться' (1) & 1 \\
\hline 4. & уважение & - & \\
\hline 5. & восхищение & - & \\
\hline 6. & удивление & $\begin{array}{l}\text { өврх ‘удивляться’ (2) } \\
\text { өврx ‘изумляться’ (1) }\end{array}$ & 3 \\
\hline 7. & вера / надежда & - & \\
\hline 8. & гордость & - & \\
\hline 9. & страх & $\begin{array}{l}ә x \text { 'бояться, пугаться, страшиться, опасаться' } \\
(19) \\
\text { сүрдx 'пугаться' (3) }\end{array}$ & 32 \\
\hline 10. & $\begin{array}{l}\text { стыд / смущение / стес- } \\
\text { нение }\end{array}$ & $\begin{array}{l}ч \chi x \text { 'стыдиться (4) } \\
\text { эмәх 'стесняться' (1) }\end{array}$ & 5 \\
\hline 11. & беспокойство / волнение & дәx 'опасаться' (4) & 4 \\
\hline 12. & растерянность & - & \\
\hline 13. & гнев / злость & уурлх 'гневаться, сердиться злиться' (7) & 7 \\
\hline 14. & раздражение & - & \\
\hline 15. & обида & $\begin{array}{l}\text { hундx 'обидеться' (4) } \\
\text { өөлх ‘обидеться’ (3) } \\
\text { hундрхх 'обидеться' (1) }\end{array}$ & 8 \\
\hline
\end{tabular}




\begin{tabular}{|l|l|l|l|}
\hline 16. & горе / печаль / огорчение & $\begin{array}{l}\text { уйдx ‘печалиться, тосковать, грустить’ (12) } \\
\text { энлх ‘сокрушаться’ (1) }\end{array}$ & 13 \\
\hline 17. & сожаление / раскаяние & - \\
\hline 18. & жалость & - \\
\hline 19. & зависть / ревность & өнгдх ‘перен. завидовать’ (1) & \\
\hline 20. & тоска по кому-л., чему л. & - \\
\hline 21. & $\begin{array}{l}\text { душевное страдание / } \\
\text { мучение }\end{array}$ & 1 \\
\hline 22. & ненависть & - & \\
\hline 23. & отвращение & - & \\
\hline 24. & $\begin{array}{l}\text { разочарование / потеря } \\
\text { надежды }\end{array}$ & - \\
\hline
\end{tabular}

Как видно из таблицы, на материале текстов эпоса выявлено лишь 10 семантических подгрупп эмотивных глаголов из 24, в которых превалируют глаголы, называющие эмоции радости (43) и страха (22), отсутствуют эмотивные глаголы, которые передают положительные эмоциональные состояния любви, уважения, восхищения и выражающие отрицательные эмоциональные состояния душевного страдания / мучения, отвращения, ненависти.

Существует и иная классификация эмотивных глаголов, которая взята нами за основу из работы О. В. Чагиной ${ }^{13}$ (см. табл. 10).

Таблица 10. Семантические группы по классификации О. В. Чагиной

[Table 10. Semantic groups (clusters) according to the classification of O. Chagina]

\begin{tabular}{|c|c|c|c|}
\hline № & $\begin{array}{c}\text { Семантические группы } \\
\text { глаголов } \\
\end{array}$ & Соотносительные глаголы & $\begin{array}{c}\text { Общее } \\
\text { количество } \\
\end{array}$ \\
\hline 1. & глаголы увлечения & - & \\
\hline 2. & глаголы удивления & $\begin{array}{l}\text { өврх ‘удивляться’ (2) } \\
\text { өврx ‘изумляться’ (1) }\end{array}$ & 3 \\
\hline 3. & глаголы любви и ненависти & - & \\
\hline 4. & $\begin{array}{l}\text { глаголы преклонения и } \\
\text { самоуничижения }\end{array}$ & - & \\
\hline 5. & $\begin{array}{l}\text { глаголы насмешки и } \\
\text { издевательства }\end{array}$ & индх 'смеяться' (12) & $12^{14}$ \\
\hline 6. & глаголы недовольства & $\begin{array}{l}\text { уурлх 'гневаться, сердиться, злиться' (7) } \\
\text { hундx 'обидеться' (4) } \\
\text { өөлх 'обидеться' (3) } \\
\text { урньх 'сердиться' (3) } \\
\text { hундрхх ‘обидеться' (1) } \\
\text { hундx ‘досадовать' (1) } \\
\end{array}$ & 19 \\
\hline 7. & глаголы боязни & $\begin{array}{l}\text { дәx ‘бояться, пугаться, опасаться, страшиться’ } \\
(15) \\
\text { сүрдх 'пугаться' (3) } \\
\text { ичх ‘стыдиться' (4) } \\
\text { эмдx 'стесняться' (1) }\end{array}$ & 23 \\
\hline 8. & глаголы беспокойства & әәх 'опасаться' (4) & 4 \\
\hline 9. & $\begin{array}{l}\text { глаголы заботы, волнений и } \\
\text { печали }\end{array}$ & $\begin{array}{l}\text { yйдx ‘печалиться’ (12) } \\
\text { энлx ‘сокрушаться’ (1) }\end{array}$ & 13 \\
\hline
\end{tabular}

${ }^{13}$ См. подробно: [Чагина 1990: 60-62].

14 Частотность глагола инәх 'смеяться' в эпосе составляет 22 словоупотребления, 10 из кото- рых называют положительные эмоции, 12 - отрицательные. 
Исходя из таблицы, представленной выше, можно сказать, что в эпосе доминируют эмотивные глаголы семантической группы глаголов боязни (23), в эпосе отстутствуют эмотивные глаголы, относящиеся к трем семантическим группам: глаголы увлечения, глаголы любви и ненависти, глаголы преклонения и самоуничижения.

В текстах эпоса зафиксированы глаголы дурлх, зовх, зовнь $x$, которые в калмыцком языке могут употребляться для передачи положительного эмоционального состояния любви и отрицательных эмоциональных состояний страдания. Анализ показал, что эти глаголы не служат для обозначения эмоциональных состояний персонажей, и мы их не включаем в список эмотивных глаголов эпоса.

\section{Выводы}

В результате анализа лексико-семантических групп эмотивных глаголов в текстах эпоса выявлено, что в частотном отношении ЛСГ «глаголы отрицательных эмоцио-

\section{Источники}

БМ - цикл песен из репертуара Мукебена Басангова (Басңһа Мукөвүн)

БН - песня из репертуара Насанки Балдырова (Балдра Наснк)

БЦ - Багацохуровский цикл

МД - Малодербетовский цикл

ОБ - песня из репертуара Бадмы Обушинова (Овшин Бадм)

ШД - цикл песен из репертуара Давы Шавалиева

ЭО — цикл песен из репертуара Овлы Эляева (Ээлян Овла)

\section{Литература}

Бабенко 1988 - Бабенко Л. Г. Эмотивная лексика в структуре предложения // Классы слов в синтагматическом аспекте / под ред. Л. Г. Бабенко. Свердловск: Изд-во Уральского гос. ун-та, 1988. С. 145-156.

Бабенко 1989 - Бабенко Л. Г. Лексические средства обозначения эмоций в русском языке. Свердловск: Изд-во Уральского унта, 1989. 184 c.

Gramota.ru - Справочно-информационный портал «Грамота.ру» [электронный ресурс] // URL: http:/gramota.ru/ (дата обращения: 20.08.2020 г.). нальных состояний» преобладает над ЛСГ «глаголы положительных эмоциональных состояний».

Частотное употребление глагола, называющего эмоцию радости ж⿻ирһx 'быть счастливым, блаженствовать', подтверждает, что наивысшим счастьем для Бумбайской страны являются мир, спокойствие и благополучие.

Анализ глагола, отражающего эмоцию боязни әәх 'бояться, пугаться, страшиться, опасаться’, показывает, что для богатыря наивысшие ценности - это преданность богдо, нерушимость клятвы, честное имя.

Для текстов эпоса характерно употребление сочетаний: эмотивный глагол + эмотивное существительное (жирhл + жирhx, hундл + hундx).

Глаголы отрицательного эмоционального состояния могут употребляться в одном контексте (әәx-uчx, әәxном синонимическом ряде (hyндx-өөлx).

\section{Sources}

Baya Dorbet (Jangar Epic) Cycle. (In Kalm.)

Baya Tsokhor (Jangar Epic) Cycle. (In Kalm.)

Cycle of Songs Recorded from Dava Shavaliev (Shavalin Dava). (In Kalm.)

Cycle of Songs Recorded from Mukeben Basangov (Basyra Mukövün). (In Kalm.)

Cycle of Songs Recorded from Ovla Elyaev (Eelyan Ovla). (In Kalm.)

Song Recorded from Badma Obushinov (Ovshin Badm). (In Kalm.)

Song Recorded from Nasanka Baldyrov (Baldra Nasnk). (In Kalm.)

Довгаль, Шепелева 2015 - Довгаль А. В., Шепелева Ю. А. Семантические особенности глаголов со значениями 'эмоциональное состояние' и 'эмоциональное отношение' в английском языке // Acta Germano-Slavica VI / ред. Е. Е. Иванов. Могилев: Могилевск. гос. ун-т им. А. А. Кулешова, 2015. С. 48-52.

КРС 1977 - Калмыцко-русский словарь / под ред. Б. Д. Муниева. М.: Русский язык, 1977. $768 \mathrm{c}$.

Куканова 2016 - Куканова В. В. Толковый словарь языка калмыцкого героического эпоса «Джангар»: принципы и проблемы составления словарных статей // «Джангар» 
и эпические традиции тюрко-монгольских народов: проблемы сохранения и исследования. Мат-лы III Междунар. науч. конф., посвящ. 75-летию Калмыцкого института гуманитарных исследований РАН (г. Элиста, 15-16 сентября 2016 г.). Элиста: КИГИ PAH, 2016. С. 7-12.

Куканова 2018 - Куканова В. В. Лексема билuг: к вопросу о происхождении и семантике (на материале эпоса «Джангар») // Oriental Studies. 2018. № 4. C. 100-121.

Манджиева 2016 - Манджиева Б. Б. О создании базы данных аутентичных текстов калмыцкого героического эпоса «Джангар»// Монголоведение. Вып. 9 / отв. ред. В. В. Куканова. Элиста: КалмНЦ РАН, 2016. С. 211217.

Манджиева 2017 - Манджиева Б. Б. К проблеме составления Свода калмыцкого фольклора // Языки и фольклор коренных народов Сибири. 2017. № 1 (32). С. 82-89.

Мулаева 2015 - Мулаева Н. М. Дефиниции растений в Толковом словаре языка калмыцкого героического эпоса «Джангар» // Урало-алтайские исследования. 2015. № 3 (18). С. 64-74.

\section{References}

Babenko L. G. Denoting Emotions in Russian: Lexical Means. Sverdlovsk: Ural State University, 1989. 184 p. (In Russ.)

Babenko L. G. Emotive vocabulary within sentence structure. In: Babenko L. G. (ed.) Word Classes in a Syntagmatic Perspective. Sverdlovsk: Ural State University, 1988. Pp. 145-156. (In Russ.)

Chagina O. V. How to Say That Differently? Sophisticating Syntactic Synonymy Skills among Non-Native Russian Speakers. Moscow: Russkiy Yazyk, 1990, 176 p. (In Russ.)

Dovgal A. V., Shepeleva Yu. A. Semantic structure of English verbs with the meaning 'emotional state' and 'emotional attitude'. In: Ivanov E. E. (ed.) Acta Germano-Slavica VI. Mogilev: Kuleshov Mogilev State University, 2015. Pp. 48-52. (In Russ.)

Gramota.ru: Reference and Information Portal. Available at: http:/gramota.ru/ (accessed: August 20, 2020). (In Russ.)

Kukanova V. V. Kalmyk Heroic Jangar Epic Explanatory Dictionary: compiling dictionary entries - principles and problems. In: Basangova T. G., Kukanova V. V., Mandzhieva
Мулаева 2017 - Мулаева Н. М. Титульные лексемы хан, хаан, хатн в Толковом словаре языка калмыцкого героического эпоса «Джангар» // Монголоведение. Вып. 10 / отв. ред. В. В. Куканова. Элиста: КалмНЦ PAH, 2017. C. 5-16.

Пюрбеев 2015а - Пюрбеев Г. Ц. Эпос «Джангар»: культура и язык (= Қаңһр дуулвр: сойл болн келн) / на рус. и калм. яз. 2-е изд., перераб. Элиста: НПП «Джангар», 2015. 280 с. Пюрбеев 20156 - Пюрбеев Г. Ц. «Смех» в калмыцком художественном тексте (по роману Эрендженова «Береги огонь») // Г. Ц. Пюрбеев. Исследования по языкам и культуре монгольских народов. Элиста: Изд-во Калмыцкого ун-та, 2015. С. 347-354.

Slovari.ru - Электронный ресурс словарей русского языка, разработанный Институтом русского языка им. В. В. Виноградова РАН [электронный ресурс] // URL: https://www. slovari.ru/ (дата обращения: 20.08.2020).

Чагина 1990 - Чагина О. В. Как сказать иначе? (Работа над синтаксической синонимией в иностранной аудитории). М.: Русский язык, 1990. 176 c.

B. B., Mikhaleva T. A. (eds.) The Jangar and Epic Traditions of Turko-Mongols: Issues of Preservation and Research. Jubilee Conference Proceedings (Elista; September 15-16, 2016). Elista: Kalmyk Humanities Research Institute of RAS, 2016. Pp. 7-12. (In Russ.)

Kukanova V. V. The lexeme biltsg: etymology and semantics revisited (a case study of the Jangar epic). Oriental Studies. 2018. No. 4. Pp. 100121. (In Russ.)

Mandzhieva B. B. On the creation of a database of authentic texts of the Kalmyk heroic epic 'Dzhangar'. In: Kukanova V. V. (ed.), Nadbitova I. S. (comp.) Mongolian Studies. Vol. 9. Elista: Kalmyk Scientific Center (RAS), 2016. Pp. 211-217. (In Russ.)

Mandzhieva B. B. To the problem of drawing up the Kalmyk Folklore Corpus. Languages and Folklore of Indigenous Peoples of Siberia. 2017. No. 1 (32). Pp. 82-89. (In Russ.)

Mulaeva N. M. Definitions of plants in the explanatory dictionary of the language of the Kalmyk heroic epic 'Dzhangar'. Ural-Altaic Studies. 2015. No. 3 (18). Pp. 64-74. (In Russ.) Mulaeva N. M. The title lexemes khan, khaan, khatn 
in the Definition Dictionary of the Kalmyk heroic epic of Jangar. In: Kukanova V. V. (ed.) Mongolian Studies. Vol. 10. Elista: Kalmyk Scientific Center (RAS), 2017. Pp. 5-16. (In Russ.)

Muniev B. D. (ed.) Kalmyk-Russian Dictionary. Moscow: Russkiy Yazyk, 1977. 768 p. (In Kalm. and Russ.)

Pyurbeev G. Ts. 'Laughter' in Kalmyk fiction: Guard the Fire by K. Erendzhenov. In: Pyurbeev
G. Ts. Studies in Mongolic Languages and Cultures. Selected Articles. Elista: Kalmyk State University, 2015. Pp. 347-354. (In Russ.) Pyurbeev G. Ts. Epic of Jangar: Culture and Language. $2^{\text {nd }}$ ed., rev. Elista: Dzhangar, 2015. 280 p. (In Russ. and Kalm.)

Russian Language Dictionaries. Online Resource by Vinogradov Russian Language Institute of the RAS. Available at: http:/www.slovari.ru/ (accessed: August 20, 2020). (In Russ.) 